\title{
Methods of Analysis by the U.S. Geological Survey Organic Geochemistry Research Group- Determination of Selected Herbicides and Their Degradation Products in Water Using Solid-Phase Extraction and Gas Chromatography/Mass Spectrometry
}

\author{
By J.L. KISH, E.M. THURMAN, E.A. SCRIBNER, and L.R. ZIMMERMAN
}

Open-File Report 00-385

Lawrence, Kansas

2000 


\section{U.S. Department of the Interior}

\section{Bruce Babbitt, Secretary}

\section{U.S. Geological Survey}

Charles G. Groat, Director

The use of firm, trade, and brand names in this report is for identification purposes only and does not constitute endorsement by the U.S. Geological Survey.

For additional information write to:

District Chief

U.S. Geological Survey

4821 Quail Crest Place

Lawrence, KS 66049-3839
Copies of this report can be purchased from:

U.S. Geological Survey

Information Services

Building 810

Box 25286, Federal Center

Denver, CO 80225-0286 


\section{CONTENTS}

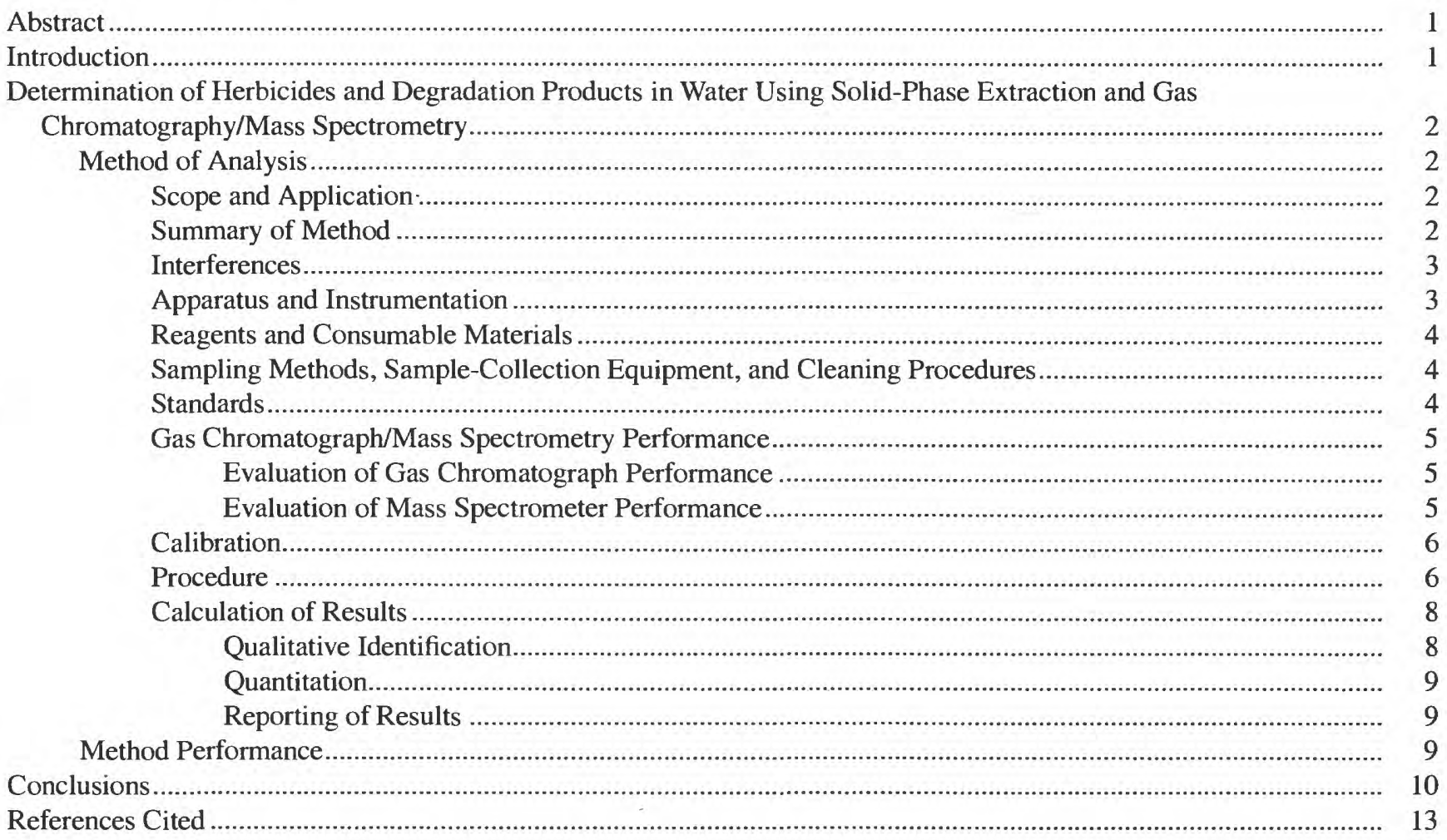

\section{FIGURES}

1. Chromatogram showing total ions of eight herbicides and five degradation products in 1.0-nanogram-permicroliter standard solution.

2. Graphs showing examples of high, intermediate, and low calibration curves for dimethenamid

TABLES

1. Herbicides and degradation products suitable for determination using method described, with registry numbers and molecular weights

2. Retention times and relative retention times of selected herbicides, degradation products, surrogate compounds, and internal standard analyzed using method described

3. Mean recoveries and relative standard deviations of selected herbicides and degradation products in reagentwater samples using gas chromatography/mass spectrometry ....

4. Mean recoveries and relative standard deviations of selected herbicides and degradation products in surfacewater samples using gas chromatography/mass spectrometry .

5. Mean recoveries and relative standard deviations of selected herbicides and degradation products in groundwater samples using gas chromatography/mass spectrometry .

6. Mean observed concentrations, standard deviations, and method detection limits of selected of herbicides and degradation products in reagent-water samples spiked at 0.05 microgram per liter

7. Absolute recoveries for selected herbicides and degradation products spiked at concentrations of 1.0 microgram per liter. 
CONVERSION FACTORS, MISCELLANEOUS ABBREVIATIONS, AND ABBREVIATED WATER-QUALITY UNITS

\section{Conversion Factors}

\begin{tabular}{rcl}
\hline Multiply & By & To obtain \\
\hline liter $(\mathrm{L})$ & 33.82 & ounce \\
gram $(\mathrm{g})$ & 0.002205 & pound \\
kilopascal & 0.1450 & pound per square inch \\
meter $(\mathrm{m})$ & 3.281 & foot \\
\hline
\end{tabular}

Temperature can be converted to degrees Celsius $\left({ }^{\circ} \mathrm{C}\right)$ or degrees Fahrenheit $\left({ }^{\circ} \mathrm{F}\right)$ by the equations:

$$
\begin{gathered}
{ }^{\circ} \mathrm{C}=5 / 9\left({ }^{\circ} \mathrm{F}-32\right) \\
{ }^{\circ} \mathrm{F}=9 / 5\left({ }^{\circ} \mathrm{C}\right)+32 .
\end{gathered}
$$

\section{Miscellaneous Abbreviations}

cubic centimeter $\left(\mathrm{cm}^{3}\right)$

inside diameter (i.d.)

mass to charge $(\mathrm{m} / \mathrm{z})$

micrometer $(\mu \mathrm{m})$

milliabsorbance units (mAU)

milligram (mg)

millimeter $(\mathrm{mm})$

millimole $(\mathrm{mM})$

milliseconds (ms)

minute (min)

nanogram (ng)

volt (V)

\section{Abbreviated Water-Quality Units}

liter per minute $(\mathrm{L} / \mathrm{min})$

microgram per liter $(\mu \mathrm{g} / \mathrm{L})$

microliter $(\mu \mathrm{L})$

milligram per milliliter $(\mathrm{mg} / \mathrm{mL})$

milliliter $(\mathrm{mL})$

milliliter per minute $(\mathrm{mL} / \mathrm{min})$

nanogram per microliter $(\mathrm{ng} / \mu \mathrm{L})$ 


\title{
Methods of Analysis by the U.S. Geological Survey Organic Geochemistry Research Group-Determination of Selected Herbicides and Their Degradation Products in Water Using Solid-Phase Extraction and Gas Chromatography/Mass Spectrometry
}

\author{
By J.L. Kish ${ }^{1}$, E.M. Thurman ${ }^{1}$, E.A. Scribner ${ }^{1}$, and L.R. Zimmerman ${ }^{2}$
}

\section{Abstract}

A method for the extraction and analysis of eight herbicides and five degradation products using solid-phase extraction from natural water samples followed by gas chromatography/mass spectrometry is presented in this report. This method was developed for dimethenamid; flufenacet; fluometuron and its degradation products, demethylfluometuron (DMFM), 3-(trifluromethyl)phenylurea (TFMPU), 3-(trifluromethyl)aniline (TFMA); molinate; norflurazon and its degradation product, demethylnorflurazon; pendamethalin; the degradation product of prometryn, deisopropylprometryn; propanil; and trifluralin. The eight herbicides are used primarily in the southern United States where cotton, rice, and soybeans are produced. The exceptions are dimethenamid and flufenacet, which are used on corn in the Midwest.

Water samples received by the U.S. Geological Survey's Organic Geochemistry Research Group in Lawrence, Kansas, are filtered to remove suspended particulate matter and then passed through disposable solid-phase extraction columns containing octadecyl-bonded porous

\footnotetext{
${ }^{1}$ U.S. Geological Survey, Lawrence, Kansas.

${ }^{2}$ University of Kansas Center for Research, Inc., Lawrence, Kansas.
}

silica (C-18) to extract the compounds. The herbicides and their degradation products are removed from the column by ethyl acetate elution. The eluate is evaporated under nitrogen, and components then are separated, identified, and quantitified by injecting an aliquot of the concentrated extract into a high-resolution, fused-silica capillary column of a gas chromatograph/mass spectrometer under selected-ion mode.

Method detection limits ranged from 0.02 to $0.05 \mu \mathrm{g} / \mathrm{L}$ for all compounds with the exception of TFMPU, which has a method detection limit of $0.32 \mu \mathrm{g} / \mathrm{L}$. The mean absolute recovery is 107 percent. This method for the determination of herbicides and their degradation products is valuable for acquiring information about water quality and compound fate and transport in water.

\section{INTRODUCTION}

This report describes a method that uses solidphase extraction (SPE) followed by gas chromatography/mass spectrometry (GC/MS) for the analysis of six herbicides and five degradation products, which are used primarily in the southern United States to enhance cotton, rice, and soybean production, and for two herbicides used in corn-growing areas of the Midwest. This method was developed by the U.S. Geological Survey (USGS) Organic Geochemistry Research Group in Lawrence, Kansas (Thurman and others, 
1992; Meyer and others, 1993; Thurman and Mills, 1998; Zimmerman and Thurman, 1999; Thurman and others, 2000).

Reconnaissance studies in the Midwest have shown widespread detection of herbicides. Approximately three-fourths of all pre-emergent herbicides in the United States are applied to row crops in a 10-State area of the midwestern United States where herbicides frequently are detected in surface water (Thurman and others, 1991; Gianessi and Puffer, 1995). Because many herbicides and their metabolites are water soluble, they may leach into ground water (Hallberg, 1989; Thurman and others, 1991; Kolpin and others, 1993) as well as transported in surface runoff (Wauchope, 1978; Leonard, 1988).

Equally important to water quality is the application of herbicides to cotton and rice in the southern United States. Cotton and rice receive three to five times more herbicides per acre than do corn or soybeans. Cotton-growing areas of the United States extend from the East Coast (The Carolinas) to the Mississippi River Delta, the Texas High Plains, and the arid deserts of the Southwest (Arizona and California). These areas of the country have different climate, precipitation, and soil types, which result in different weed and insect pressures, as well as different runoff potentials; therefore, leaching patterns often are different. Because of these considerations, the types and amounts of herbicides applied may vary considerably throughout cotton-growing areas (Coupe and others, 1998; Thurman and others, 2000).

The analytical method described in this report was developed by the USGS to determine concentrations of the following herbicides and their degradation products: dimethenamid; flufenacet; fluometuron and its degradation products, demethylfluometuron (DMFM), 3-(trifluromethyl)phenylurea (TFMPU), 3-(trifluromethyl)aniline (TFMA); molinate; norflurazon and its degradation product, demethylnorflurazon; pendamethalin; the degradation product of prometryn, deisopropylprometryn; propanil; and trifluralin. The GC/MS method of analysis described in this report has been assigned the method code "O-2132-99." This unique code represents the automated method of analysis for organic compounds as it is described in this report and can be used to identify the method.

This report provides a detailed description of the method, including the apparatus, reagents, instrument calibration, and the SPE procedure required for sample analysis. Method detection limits, mean extraction recoveries, and relative standard deviations for the GC/MS methods also are presented.

\section{DETERMINATION OF HERBICIDES AND DEGRADATION PRODUCTS IN WATER USING SOLID-PHASE EXTRACTION AND GAS CHROMATOGRAPHY/MASS SPECTROMETRY}

\section{Method of Analysis (0-2132-99)}

\section{Scope and Application}

The method described in this report is suitable for the determination of low concentrations (in micrograms per liter) of selected cotton, rice, soybean, and corn herbicides and their degradation products in natural water samples. Registry numbers and molecular weights are shown in table 1 for each herbicide and degradation product. This method is applicable to herbicides and their degradation products that are (1) efficiently partitioned from the water phase onto an octadecyl (C-18) silica phase that is chemically bonded to a solid silica matrix and (2) sufficiently volatile and thermally stable for gas chromatography. Suspended particulate matter is removed from the samples by filtration, so this method is suitable only for dissolved-phase herbicides and their degradation products.

Herbicides were selected for analysis because of their extensive use in the United States and their importance to studies being conducted by the USGS. The calibration range for the method is equivalent to concentrations from 0.05 to $5.0 \mu \mathrm{g} / \mathrm{L}$ without dilution.

\section{Summary of Method}

Natural water samples are filtered at the collection site using glass-fiber filters with a $0.7-\mu \mathrm{m}$ nominal pore diameter to remove suspended particulate matter. In the laboratory, filtered water samples are passed through a preconditioned $\mathrm{C}-18$ column. The adsorbed compounds are removed from the $\mathrm{C}-18$ with ethyl acetate. The eluate is evaporated further under nitrogen. The sample components are separated, identified, and quantified by injecting an aliquot of the concentrated extract into a high-resolution, fused-silica capillary column of a GC/MS system under selected-ion mode 
Table 1. Herbicides and degradation products suitable for determination using method described, with registry numbers and molecular weights

[CAS. Chemical Abstract Service: DP, degradation product; AMID, amide; PU, phenylurea; TC, thiocarbamate; PDZ. pyridazinone: DNA, dinitroaniline; --, not available]

\begin{tabular}{llcc}
\hline $\begin{array}{c}\text { Herbicide or } \\
\text { degradation product }\end{array}$ & \multicolumn{1}{c}{ Class } & $\begin{array}{c}\text { CAS registry } \\
\text { number }\end{array}$ & $\begin{array}{c}\text { Molecular weight } \\
\text { (atomic mass } \\
\text { units) }\end{array}$ \\
\hline Deisopropylprometryn & DP & -- & 199 \\
Demethylfluometuron (DMFM) & DP & -- & 218 \\
Demethylnorflurazon & DP & -- & 289 \\
Dimethenamid & AMID & $87674-68-8$ & 275 \\
Flufenacet & AMID & $142459-58-3$ & 363 \\
& & & \\
Fluometuron & PU & $2164-17-2$ & 232 \\
Molinate & TC & $2212-67-1$ & 187 \\
Norflurazon & PDZ & $27314-13-2$ & 303 \\
Pendimethalin & DNA & $40487-42-1$ & 281 \\
Propanil & AMID & $709-98-8$ & 218 \\
& & & \\
3-(trifluromethyl)aniline (TFMA) & DP & -- & 161 \\
3-(trifluromethyl)phenylurea (TFMPU) & DP & -- & 204 \\
Trifluralin & DNA & $1582-09-08$ & 335 \\
\hline
\end{tabular}

(SIM). Compounds eluting from the GC column are identified by comparing their measured ions and retention times to reference ions and retention times obtained by the measurement of control standards under the same conditions used for the water samples. The concentration of each identified compound is measured by relating the MS response of the quantitation ion produced by that compound to the MS response of the quantitation ion produced by a compound that is used as an internal standard. Surrogate compounds, whose concentrations are known in every sample, are measured with the same calibration procedure.

\section{Interferences}

Organic compounds having identical mass characteristic ions and GC retention times to those of the herbicides and their degradation products of interest may interfere.

\section{Apparatus and Instrumentation}

- Analytical balances-Capable of accurately weighing $0.0100 \mathrm{~g} \pm 0.0001 \mathrm{~g}$.
- Autopipettes-10-, 100-, and 200- $\mu \mathrm{L}$, variablevolume autopipettes with disposable tips (Rainin, Woburn, MA, or equivalent).

- Tekmar six-position AutoTrace-Automated SPE workstation (Tekmar-Dohrmann, Cincinnati, $\mathrm{OH})$.

- Extraction software-Tekmar AutoTrace Extraction software, version 1.33 (Tekmar-Dohrmann, Cincinnati, $\mathrm{OH}$ ).

- Automated solvent evaporator-The heat-bath temperature needs to be maintained at $45^{\circ} \mathrm{C}$ and the nitrogen gas pressure at 103 kilopascals (Turbovap LV or equivalent, Zymark Inc., Hopkinton, MA).

- Fused-silica capillary column-Cross-linked methyl siloxane capillary column ( $12 \mathrm{~m}$ x $0.2 \mathrm{~mm}$ i.d., 0.33- $\mu \mathrm{m}$ film thickness) (HP Ultra 1 or equivalent, Hewlett Packard, Wilmington, DE).

- GC/MS benchtop system-Hewlett Packard (Wilmington, DE) model 5890 series II Plus or equivalent GC with autoinjector connected to a Hewlett Packard model 5970 or equivalent MS detector.

- GC conditions-Oven, $60{ }^{\circ} \mathrm{C}$ (hold $1 \mathrm{~min}$ ), then ramp to $200^{\circ} \mathrm{C}$ at $6{ }^{\circ} \mathrm{C} / \mathrm{min}$, then $30{ }^{\circ} \mathrm{C} / \mathrm{min}$ to $250^{\circ} \mathrm{C}$, and hold for $4 \mathrm{~min}$; 
injection port, $210{ }^{\circ} \mathrm{C}$; carrier gas, helium; injection volume, $2 \mu \mathrm{L}$, splitless injection.

- MS conditions-Multiplier, 400 over autotune; detector, $280{ }^{\circ} \mathrm{C}$; dwell time, $25 \mathrm{~ms}$; mass ions monitored are listed in table 2 (see section on "Calibration").

- Moisture sieve and oxygen scrubber for carrier gas.

- Data system-Computer and printer compatible with the GC/MS system used.

- Software-HP DOS ChemStation Software, 1030A version C (Hewlett Packard, Wilmington, DE) is used to acquire and store data and for peak integration.

\section{Reagents and Consumable Materials}

- Sample bottles-Baked 125-mL amber glass bottles (Boston round) with Teflon-lined lids.

- Sample filters-A $0.70-\mu \mathrm{m}$ glass-fiber filter (Gilson, Middleton, WI).

- Reagent water-Generated by purification through activated charcoal filtration and deionization with a high-purity, mixed-bed resin, followed by another activated charcoal filtration, and finally distillation in an autostill (Wheaton or equivalent, Millville, NJ).

- Analytical standards-Standards of the triazine and chloroacetanilide compounds.

- SPE columns-C-18 SEP-PAK Plus, containing $360 \mathrm{mg}$ of $40-\mu \mathrm{m} \mathrm{C}-18$ bonded-silica packing (Waters, Milford, MA).

- Disposable snap-cap finish centrifuge tubes$10 \mathrm{~mL}$ (Kimble or equivalent, Vineland, NJ).

- Solvents-Ethyl acetate [American Chemical Society (ACS) grade] and methanol [highperformance liquid chromatography grade (HPLC)].

- Gas for evaporation-Nitrogen, ultrapure grade.

- Pasteur pipettes-(Kimble or equivalent, Vineland, $\mathrm{NJ})$.

- 0.1-mL autosampler vials-Plastic vials with glass cone inserts (Wheaton, Millville, NJ).

- GC carrier gas-Helium, ultrapure grade.

\section{Sampling Methods, Sample-Collection Equipment, and Cleaning Procedures}

Following USGS protocol, surface-water samples are collected with a depth-integrating technique at three or more locations across each stream (Ward and Harr, 1990). The water samples from each site are composited in a single glass container or Teflon bottle.
Samples are withdrawn from the compositing container and filtered through a $0.70-\mu \mathrm{m}$ glass-fiber filter using a peristaltic pump. Filters are leached with about $200 \mathrm{~mL}$ of sample prior to filtration of sample. The filtered material for analysis is collected in baked 125-mL amber glass bottles with Teflon-lined lids. Samples are chilled immediately and shipped to the laboratory within 3 days of collection. At the laboratory, samples are logged in, assigned identification numbers, and refrigerated at $4{ }^{\circ} \mathrm{C}$ until extracted and analyzed.

\section{Standards}

- Stock standard solutions-Obtain herbicides, degradation products, internal standard, and surrogate standards as pure materials from commercial vendors or chemical manufacturers. If pure materials are obtained, prepare solutions of $1 \mathrm{mg} / \mathrm{mL}$ by accurately weighing, to the nearest $0.1 \mathrm{mg}$, $50 \mathrm{mg}$ of the pure material in a $50-\mathrm{mL}$ volumetric flask and dilute with methanol. Transfer the stock solutions to clean $2-\mathrm{mL}$ vials and store in a freezer. These solutions are stable for about 24 months.

- Primary fortification standard-A solution containing all the compounds for analysis at a known concentration. This standard is used in the preparation of control samples. Prepare a 1.23-ng/ $\mu \mathrm{L}$ concentration, primary fortification standard solution by combining appropriate volumes of the individual stock solutions in a 1-L volumetric flask. Use adjustable autopipette to dispense an appropriate volume and dilute with methanol. Store at less than $4^{\circ} \mathrm{C}$. This solution is stable for about 24 months.

- Internal standard solution-Herbicides are ratioed against an internal standard to determine concentration. Prepare a solution of phenanthrene- $d_{10}$ in ethyl acetate at a concentration of $0.2 \mathrm{ng} / \mu \mathrm{L}$. The internal standard may be purchased as a $100-\mu \mathrm{g} / \mathrm{mL}$ solution in methylene chloride. Dilute $800 \mu \mathrm{L}$ in $4 \mathrm{~L}$ of ethyl acetate. Store at less than $4{ }^{\circ} \mathrm{C}$. This solution is stable for about 12 months.

- Surrogate solution-A secondary compound used to determine the final concentration. The surrogate has the same function as the internal standard except it is spiked into the water. Prepare solutions of atrazine- $\mathrm{d}_{5}$ and terbuthylazine in methanol at concentrations of $1.23 \mathrm{ng} / \mu \mathrm{L}$. If 
pure materials are obtained, prepare solutions of $1 \mathrm{mg} / \mathrm{mL}$ by accurately weighing, to the nearest $0.001 \mathrm{mg} .50 \mathrm{mg}$ of the pure material in a $50-\mathrm{mL}$ volumetric flask and dilute with methanol. Transfer the stock solutions to clean vials and store in a freezer. This solution is stable for about 24 months.

- Calibration solution-Prepare a calibration solution using the primary fortification standard in water that contains all target herbicides and metabolites. This solution is spiked at concentrations from 0.05 to $5.0 \mu \mathrm{g} / \mathrm{L}(0.05,0.1,0.2,0.5,1.0,2.0$, and $5.0 \mu \mathrm{g} / \mathrm{L}$ ) and the surrogate standards, atrazine- $\mathrm{d}_{5}$ and terbuthylazine, at a constant concentration of $1 \mu \mathrm{g} / \mathrm{L}$.

\section{Gas Chromatography/Mass Spectrometry Performance}

\section{Evaluation of Gas Chromatograph Performance}

Gas chromatograph performance is evaluated by peak shape, internal standard response, and by comparison of response factors relative to response factors obtained using a new capillary column and freshly prepared calibration solutions (a standard curve). An example of the separation and peak shape of cotton, rice, soybean, and corn herbicides and degradation products and internal standards is shown in a total ion chromatogram of a $1.0-\mu \mathrm{g} / \mathrm{L}$ standard solution (fig. 1).

If peak shape deteriorates or if response factors fail to meet the calibration criteria, the injection liner is changed, or maintenance on the capillary column is performed to bring the gas chromatograph into compliance. Part of the inlet end on the capillary column may be removed to restore performance. Specifically, poor peak shape and a loss of response for the herbicides and degradation products susceptible to loss on injection indicate a need for immediate action.

\section{Evaluation of Mass Spectrometer Performance}

Mass spectrometer performance is evaluated by assessing isotopic ratios, contamination, electron multiplier sensitivity, and abundance.

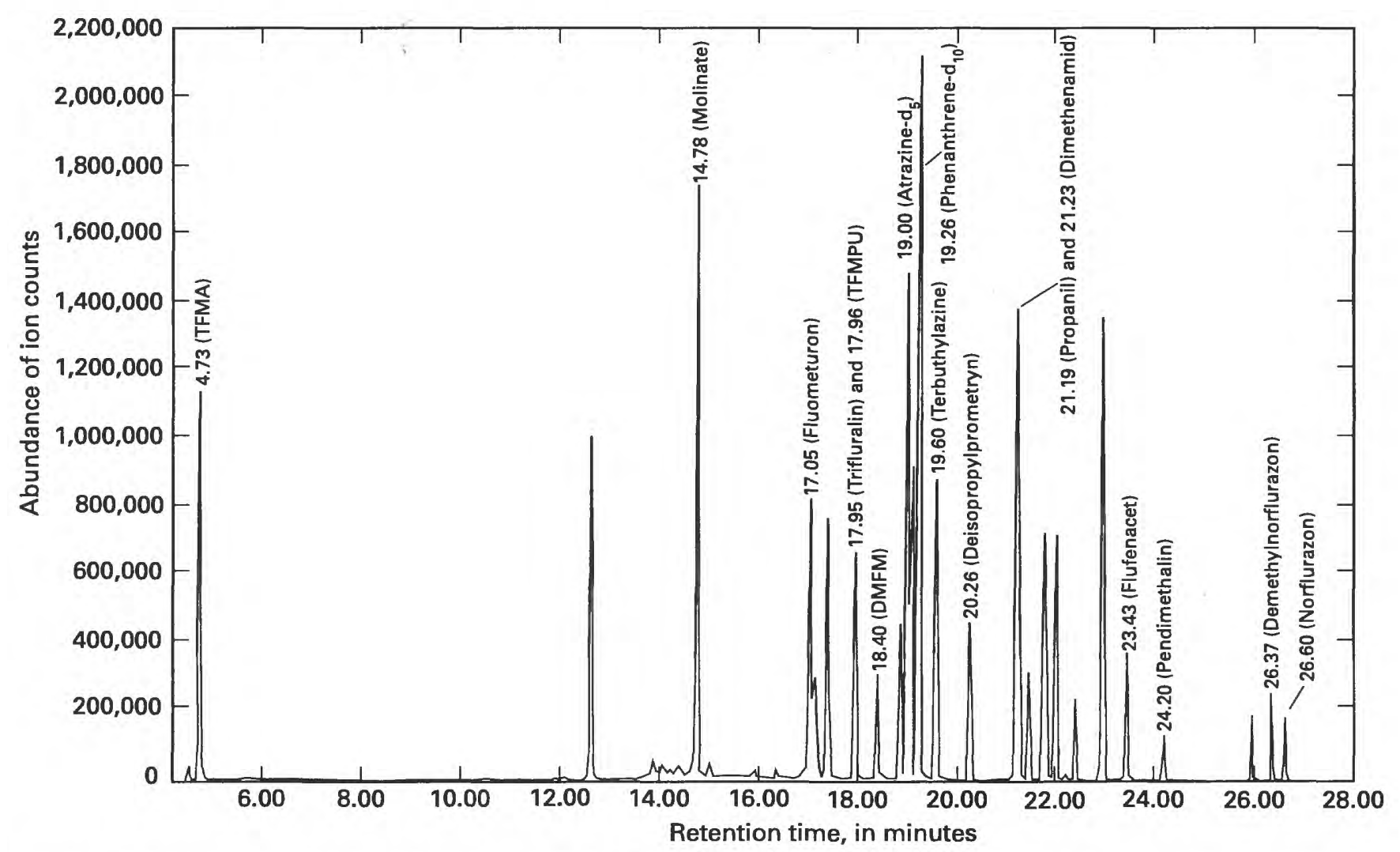

Figure 1. Chromatogram showing total ions of eight herbicides and five degradation products in 1.0-nanogram-per-microliter standard solution. Retention times shown above each peak correspond to compounds listed in table 2. 
- Tune the mass spectrometer before each GC/MS sample set (approximately 43 injections or three extraction sample sets) using the procedure and software supplied by the manufacturer. Parameters in the tuning software are set to give \pm 0.15 atomic mass unit resolution at masses 69 , 219 , and 502 in the spectrum of perfluorotributylamine (PFTBA). With the resolution of the 69 ion at 100-percent abundance, the mass 219 ion should be $35 \pm 20$ percent, and the mass 502 ion should be more than 3 percent relative abundance; however, their masses may vary depending on the mass spectrometer used. Check mass assignments to ensure accuracy to \pm 0.15 atomic mass units and that mass peak widths measured at one-half the peak height range from about 0.50 to 0.60 atomic mass units.

- Also, during the tuning of the mass spectrometer, check the mass spectrometer for the presence of excessive water and air, which indicate leaks in the vacuum. If detected, locate and fix leaks.

- Initially adjust the electron multiplier of the mass spectrometer to ensure that the established reporting level for each selected compound can be achieved.

\section{Calibration}

- Acquire initial calibration data by using a new capillary column and freshly prepared calibration solutions. Use these data in the subsequent evaluation of GC/MS performance.

- Acquire data for each calibration solution by injecting $2 \mu \mathrm{L}$ of each solution into the GC/MS according to the conditions already described. Calculate the relative retention time $\left(R R T_{c}\right)$ for each selected compound and the surrogate compounds in the calibration solution or in a sample as follows:

$$
R R T_{c}=\frac{R T_{c}}{R T_{i}},
$$

where $R T_{c}=$ uncorrected retention time of the quantitation ion of the selected compound or surrogate compound, and

$$
R T_{i}=\text { uncorrected retention time of the }
$$
quantitation ion of the internal standard (phenanthrene- $d_{10}$ ).

See table 2 for an example of retention times and relative retention times.
- Initial calibration data are entered into a computer spreadsheet (Microsoft Excel, Microsoft, Inc., Seattle, WA), and ratios are calculated for each quantitation ion relative to the internal standard (phenanthrene- $d_{10}$ ). Graphs are made from the GC/MS data by plotting the correlation curve with the phenanthrene- $d_{10}$ ratios of a single ion on the $\mathrm{x}$ axis and the concentrations of the standards used on the $y$ axis. Three graphs are made for each ion, one with concentrations ranging from 0 to $0.20 \mu \mathrm{g} / \mathrm{L}$, another with concentrations ranging from 0.20 to $2.0 \mu \mathrm{g} / \mathrm{L}$ (fig. 2), and the final curve ranging from 0.2 to $5.0 \mu \mathrm{g} / \mathrm{L}$. This gives an intermediate and a low curve to keep the response linear. The final curve is a quadratic curve that is used to give high-end results. The low curve is plotted with one point at 0 . The spreadsheet determines slopes, $y$ intercepts, and correlation coefficient values $\left(\mathrm{r}^{2}\right)$ for the graphs.

- Initial calibration data acquired using a new capillary column and fresh calibration solutions are acceptable if the correlation coefficient $\left(\mathrm{r}^{2}\right)$ value for all curves is greater than or equal to 0.99 for all compounds.

- Subsequent daily response factors calculated for the majority of compounds need to agree within \pm 20 percent of the mean response factor for the compounds analyzed. A response factor is equal to the area of the quantitation ion for the selected compound or surrogate divided by the area of the quantitation ion for the internal standard. Analyze at least two calibration standards with each sample set, one high calibration standard ranging from 0.5 to $2.0 \mu \mathrm{g} / \mathrm{L}$ and one low standard ranging from 0.05 to $0.20 \mu \mathrm{g} / \mathrm{L}$ to verify instrument response in each range.

\section{Procedure}

- Sample preparation - In the automation of sample extraction, the Autotrace workstation is used (Tekmar-Dohrman, Cincinnati, OH). Should an environmental sample contain less than $123 \mathrm{~mL}$, distilled water is added to bring the volume to the required $123 \mathrm{~mL}$. Any volume added is recorded. An extraction sample set consists of eight samples, one duplicate sample, two standard control samples (one high concentration and one low concentration), and one blank control sample. Each bottle is spiked with the surrogate standard solution, atrazine- $\mathrm{d}_{5}$ and terbuthylazine, at a con- 
Table 2. Retention times and relative retention times of selected herbicides, degradation products, surrogate compounds, and internal standard analyzed using method described

[min, minute: $\mathrm{m} / \mathrm{z}$. mass-to-charge ratio: --, not applicable]

\begin{tabular}{|c|c|c|c|c|c|}
\hline Compound & $\begin{array}{l}\text { Retention time } \\
\text { (min) }\end{array}$ & $\begin{array}{c}\text { Relative } \\
\text { retention time } \\
\text { (dimensionless) }\end{array}$ & $\begin{array}{c}\text { Quantitation } \\
\text { ion } \\
(\mathrm{m} / \mathrm{z})\end{array}$ & $\begin{array}{l}\text { Confirmation } \\
\text { ion } 1 \\
(\mathrm{~m} / \mathrm{z})\end{array}$ & $\begin{array}{c}\text { Confirmation } \\
\text { ion } 2 \\
(\mathrm{~m} / \mathrm{z})\end{array}$ \\
\hline \multicolumn{6}{|c|}{ Herbicides or degradation products (in order of increasing retention time) } \\
\hline 3-(trifluromethyl)aniline (TFMA) & 4.73 & 0.25 & 161 & 142 & 114 \\
\hline Molinate & 14.78 & .77 & 126 & 55 & 187 \\
\hline Fluometuron & 17.05 & .89 & 72 & 232 & - \\
\hline Trifluralin & 17.95 & .93 & 264 & 306 & -- \\
\hline $\begin{array}{l}\text { 3-(trifluromethyl)phenylurea } \\
\text { (TFMPU) }\end{array}$ & 17.96 & .93 & 161 & 204 & 142 \\
\hline Demethylfluometuron (DMFM) & 18.40 & .96 & 161 & 58 & 142 \\
\hline Deisopropylprometryn & 20.26 & 1.05 & 184 & 199 & 157 \\
\hline Propanil & 21.19 & 1.10 & 161 & 217 & -- \\
\hline Dimethenamid & 21.23 & 1.10 & 154 & 230 & 203 \\
\hline Flufenacet & 23.43 & 1.22 & 151 & 211 & 123 \\
\hline Pendimethalin & 24.20 & 1.26 & 252 & 281 & 162 \\
\hline Demethylnorflurazon & 26.37 & 1.37 & 289 & 145 & 291 \\
\hline Norflurazon & 26.60 & 1.38 & 303 & 145 & 102 \\
\hline \multicolumn{6}{|c|}{ Surrogate compounds } \\
\hline Atrazine- $\mathrm{d}_{5}$ & 19.00 & -- & 205 & 220 & -- \\
\hline Terbuthylazine & 19.60 & -- & 214 & 229 & -- \\
\hline \multicolumn{6}{|c|}{ Internal standard } \\
\hline Phenanthrene- $d_{10}$ & 19.26 & 1.00 & 188 & -- & -- \\
\hline
\end{tabular}

centration of $1.0 \mu \mathrm{g} / \mathrm{L}(100 \mu \mathrm{L}$ of $1.23-\mathrm{ng} / \mu \mathrm{L}$ surrogate solution into $123 \mathrm{~mL}$ ) with an autopipette.

- Workstation preparation-Before a sample set is extracted on the automated workstation, each port is flushed with $15 \mathrm{~mL}$ of methanol:water $(4: 1)$ and then again with distilled water. All SPE columns, test tubes, reagents, working solvents, surrogate spike, and samples then are loaded onto the instrument.

- Conditioning the SPE columns-The workstation conditions each SPE column by sequentially passing $1 \mathrm{~mL}$ methanol, $1 \mathrm{~mL}$ ethyl acetate, $1 \mathrm{~mL}$ methanol, and $3 \mathrm{~mL}$ distilled water through each column at a flow rate of $10 \mathrm{~mL} / \mathrm{min}$ by positive pressure.

- Loading the sample $-123 \mathrm{~mL}$ of sample is passed through the SPE column at a flow rate of $20 \mathrm{~mL} / \mathrm{min}$.

- Eluting the SPE column-Each SPE column is eluted with $4.0 \mathrm{~mL}$ ethyl acetate to remove the compounds at a flow rate of $2 \mathrm{~mL} / \mathrm{min}$.
- Spiking of internal standard solution-After all the samples in a set have been loaded and eluted, $500 \mu \mathrm{L}$ of $0.2-\mathrm{ng} / \mu \mathrm{L}$ phenanthrene- $d_{10}$ solution is hand spiked into each eluate.

- Separation of ethyl acetate and residual waterDue to water in the SPE column that is eluted with the ethyl acetate, the ethyl acetate is transferred off of the aqueous phase into another tube. This is done manually using a pasteur pipette.

- Evaporation-The spiked eluate then is evaporated to approximately $75 \mu \mathrm{L}$ under nitrogen in a water bath at $45^{\circ} \mathrm{C}$.

- Transfer to vials-Using a baked disposable Pasteur pipette, the eluate is withdrawn from the 10-mL glass centrifuge tube into a pipette, and transferred to an appropriately labeled GC autosampler vial containing a $0.1-\mathrm{mL}$ insert for GC/MS analysis. The GC autosampler vial is capped and stored at less than $4{ }^{\circ} \mathrm{C}$ until analysis by GC/MS. 

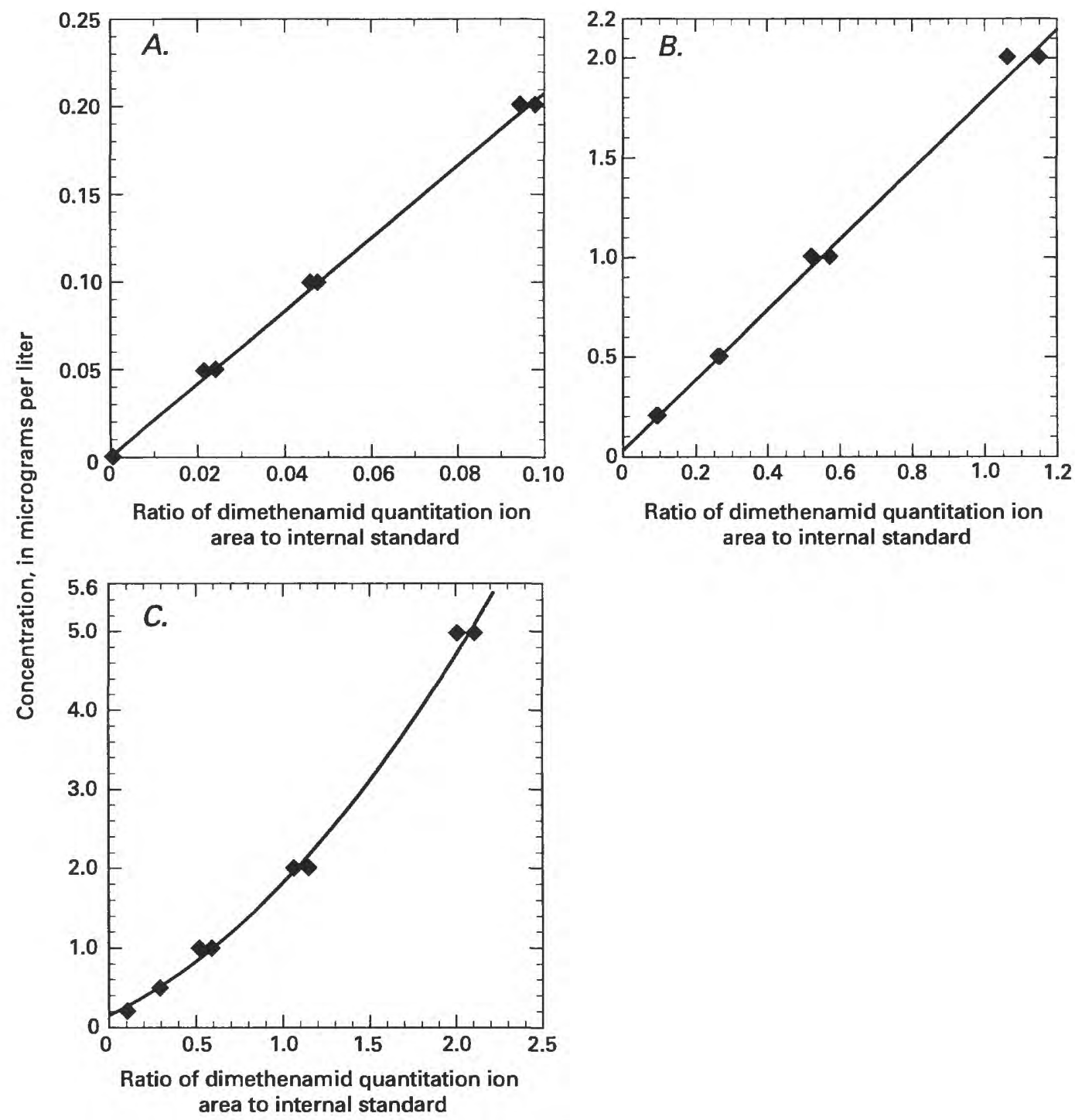

Figure 2. Examples of high, intermediate, and low calibration curves for dimethenamid. (A) low calibration curve for dimethenamid with a linear curve fit, $(B)$ intermediate calibration curve for dimethenamid with a linear curve fit, and $(C)$ high calibration curve for dimethenamid with a quadratic curve fit.

- Sample analysis and data evaluation-Ensure that GC/MS conditions for the analysis of the selected compounds in sample extracts are the same as those used in the analysis of the calibration solutions. Prior to the analysis of any sample extracts, ensure that the GC performance evaluation criteria have been met. Inject $2 \mu \mathrm{L}$ of the sample extract and acquire data using the GC/MS conditions described.

\section{Calculation of Results}

\section{Qualitative Identification}

- The expected retention time $(R T)$ of the GC peak of the quantitation ion for the selected compound of interest needs to be within \pm 6 seconds of the expected retention time that is based on the $R R T_{c}$ obtained from the analysis of the internal stan- 
dard. Calculate the expected retention time as follows:

$$
R T=\left(R R T_{c}\right)\left(R T_{i}\right),
$$

where $R T=$ expected retention time of the selected compound or surrogate compound,

$$
\begin{aligned}
R R T_{\mathrm{r}}=\quad & \text { relative retention time of the } \\
& \text { selected compound or surrogate } \\
& \text { compound, and }
\end{aligned}
$$

$R T_{i}=$ uncorrected retention time of the quantitation ion of the internal standard.

- Mass-spectral verification for each selected compound is done by comparing the relative integrated abundance values of the selected ions monitored with the relative integrated abundance values obtained from the standard control samples. The relative ratios of the ions need to be within \pm 20 -percent of the relative ratios of those obtained in the absence of any obvious interferences. Slopes for compounds that interact with the $\mathrm{GC}$ inlet are modified to meet the \pm 20 -percent criteria. As samples are analyzed, the heated inlet is coated with an involatile residue. Over time, this residue builds up and causes specific sorption of some analytes, which is an inhibitory factor. The charts monitor the surrogate-to-internal-standard ratio; if the ratio is not within 20 percent of its mean, then a new standard curve is analyzed. These modifications from 0 to 20 percent are referred to as the correction factor in equation 4.

\section{Quantitation}

- Calculate the volume of sample processed as follows:

$$
D F=\left(\frac{123}{123-V_{n p}}\right)\left(\frac{123}{123-V_{a}}\right),
$$

where $D F=$ dilution factor,

$V_{n p}=$ volume not pumped, in milliliters, and

$V_{a}=$ volume added, in milliliters.

The dilution factor is incorporated into the calculation for determining final concentrations in samples.

- If a selected compound has passed the aforementioned qualitative identification criteria, calculate the concentration in the sample as follows:

$$
C=\left[\left(\left(\frac{A_{c}}{A_{i}}\right)(m)+y\right)(D F)\right] x C F,
$$

where $C=$ concentration of the selected compound or surrogate compound in the sample, in micrograms per liter;

$A_{c}=$ area of the quantitation ion for the selected compound or surrogate identified;

$A_{i}=$ area of the quantitation ion for the internal standard;

$m$ = slope of correlation curve between the selected compound and phenanthrene- $d_{10}$ from the original calibration data;

$y=\mathrm{y}$ intercept of correlation curve between the selected compound and phenanthrene- $d_{10}$ from the original calibration data;

$D F=$ dilution factor as described in equation 3 ; and

$C F=$ correction factor.

\section{Reporting of Results}

Concentrations of herbicides and degradation products are reported from 0.05 to $5.0 \mu \mathrm{g} / \mathrm{L}$ without dilution. If the concentration is greater than $5.0 \mu \mathrm{g} / \mathrm{L}$, the sample extract is diluted (volume increased to approximately $150 \mu \mathrm{L}$ with eluting solvent) and reanalyzed. If the concentration is greater than $10 \mu \mathrm{g} / \mathrm{L}$, the sample is re-extracted with a 1:10 dilution (sample:distilled water) and re-analyzed for those compounds with concentrations greater than $10 \mu \mathrm{g} / \mathrm{L}$.

\section{Method Performance}

A reagent-water sample, a surface-water sample collected from Poison Creek in Valley County, Idaho, and a ground-water sample collected from a well in Valley County, Idaho, were used to test the performance of the GC/MS method. The surface- and ground-water samples were collected in 45-L carboys and were split into 123-mL samples. One set of seven samples was spiked with $0.2 \mu \mathrm{g} / \mathrm{L}$ of each herbicide and degradation product of interest, and one set of samples was spiked with $1.0 \mu \mathrm{g} / \mathrm{L}$ of each herbicide and degradation product of interest. In addition, unspiked samples of surface and ground water were extracted and analyzed to determine background 
concentrations of the herbicides and degradation products. All subsamples were analyzed in one laboratory, the USGS Organic Geochemistry Research Laboratory in Lawrence, Kansas, using one GC/MS system. Each sample set was extracted and analyzed on different days intermittently between sample sets so that comparison of different matrices and concentrations included bias from day-to-day variation. Method recoveries from the analyses are listed in tables 3 through 5 .

Mean recovery: Mean recovery in reagent-, surface-, and ground-water samples was determined by comparing the mean calculated concentration from seven replicate samples as shown in the "Quantitation" section to the spiked concentration $(0.2 \mu \mathrm{g} / \mathrm{L})$.

Corrections for background concentrations: Neither surface- nor ground-water samples required correction for background concentrations of compounds. All unfortified reagent-water samples also had no detections.

Method detection limits (MDL's): An MDL is defined as the minimum concentration of a compound that can be identified, measured, and reported with a 99-percent confidence that the compound concentration is greater than zero. MDL's were determined according to procedures outlined by the U.S. Environmental Protection Agency (1992). Seven replicate samples of reagent water fortified at $0.05 \mu \mathrm{g} / \mathrm{L}$ were analyzed to determine MDL's (table 6). Each sample was analyzed on different days during May and June 1998, so day-to-day variation was included.

The MDL was calculated using the following equation:

$\begin{array}{ll}M D L= & (S)\left(t_{(n-1,1-\alpha=0.99)}\right), \\ \text { where } \quad S=\quad \begin{array}{l}\text { standard deviation of the replicate } \\ \text { analyses, in micrograms per liter, } \\ \text { at the spiked concentration; }\end{array} \\ t_{(\mathrm{n}-1,1-\alpha=0.99)=} \begin{array}{l}\text { Student's } t \text { value for the } 99- \\ \text { percent confidence level with } n-1 \\ \text { degrees of freedom (U.S. Envi- } \\ \text { ronmental Protection Agency, } \\ \text { 1992); and }\end{array} \\ \text { number of replicate analyses. }\end{array}$

(1)

(1)
concentrations of the selected herbicides and degrada- tion products in natural water samples.

Concentrations of herbicides and degradation products are reported from 0.05 to $5.0 \mu \mathrm{g} / \mathrm{L}$ without dilution. Method detection limits ranged from 0.02 to $0.05 \mu \mathrm{g} / \mathrm{L}$ for all compounds with the exception of TFMPU, which has a method detection limit of $0.32 \mu \mathrm{g} / \mathrm{L}$. The mean absolute recovery for all compounds is 107 percent. 
Table 3. Mean recoveries and relative standard deviations of selected herbicides and degradation products in reagentwater samples using gas chromatography/mass spectrometry

[ $\mu \mathrm{g} / \mathrm{L}$. micrograms per liter: RSD. relative standard deviation]

\begin{tabular}{|c|c|c|c|c|}
\hline \multirow[b]{3}{*}{$\begin{array}{l}\text { Herbicide or } \\
\text { degradation product }\end{array}$} & \multicolumn{4}{|c|}{ Reagent water } \\
\hline & \multicolumn{2}{|c|}{$\begin{array}{l}\text { Seven replicate samples spiked at } \\
\qquad 0.2 \mu \mathrm{g} / \mathrm{L}\end{array}$} & \multicolumn{2}{|c|}{$\begin{array}{l}\text { Seven replicate samples spiked at } \\
\qquad 1.0 \mu \mathrm{g} / \mathrm{L}\end{array}$} \\
\hline & $\begin{array}{l}\text { Mean recovery } \\
\text { (percent) }\end{array}$ & RSD & $\begin{array}{l}\text { Mean recovery } \\
\text { (percent) }\end{array}$ & RSD \\
\hline Deisopropylprometryn & 120 & 0.12 & 103 & 0.10 \\
\hline Demethylfluometuron (DMFM) & 111 & .04 & 105 & .15 \\
\hline Demethylnorflurazon & 86 & .04 & 79 & .17 \\
\hline Dimethenamid & 109 & .06 & 98 & .05 \\
\hline Flufenacet & 108 & .05 & 97 & .12 \\
\hline Fluometuron & 101 & .02 & 92 & .09 \\
\hline Molinate & 101 & .05 & 91 & .13 \\
\hline Norflurazon & 83 & .05 & 78 & .15 \\
\hline Pendimethalin & 130 & .08 & 98 & .15 \\
\hline Propanil & 111 & .05 & 104 & .13 \\
\hline 3-(trifluromethyl)aniline (TFMA) & 90 & .07 & 90 & .17 \\
\hline 3-(trifluromethyl)phenylurea (TFMPU) & 81 & .11 & 75 & .18 \\
\hline Trifluralin & 113 & .07 & 82 & .11 \\
\hline
\end{tabular}

Table 4. Mean recoveries and relative standard deviations of selected herbicides and degradation products in surface-water samples using gas chromatography/mass spectrometry

[ $\mu \mathrm{g} / \mathrm{L}$, micrograms per liter; RSD, relative standard deviation]

\begin{tabular}{|c|c|c|c|c|}
\hline \multirow[b]{3}{*}{ Herbicide or degradation product } & \multicolumn{4}{|c|}{ Surface water } \\
\hline & \multicolumn{2}{|c|}{$\begin{array}{c}\text { Seven replicate samples spiked at } \\
0.2 \mu \mathrm{g} / \mathrm{L}\end{array}$} & \multicolumn{2}{|c|}{$\begin{array}{l}\text { Seven replicate samples spiked at } \\
\qquad 1.0 \mu \mathrm{g} / \mathrm{L}\end{array}$} \\
\hline & $\begin{array}{l}\text { Mean recovery } \\
\text { (percent) }\end{array}$ & RSD & $\begin{array}{l}\text { Mean recovery } \\
\text { (percent) }\end{array}$ & RSD \\
\hline Deisopropylprometryn & 112 & 0.03 & 96 & 0.16 \\
\hline Demethylfluometuron (DMFM) & 130 & .06 & 125 & .24 \\
\hline Demethylnorflurazon & 95 & .04 & 94 & .18 \\
\hline Dimethenamid & 109 & .02 & 104 & .08 \\
\hline Flufenacet & 127 & .03 & 112 & .06 \\
\hline Fluometuron & 109 & .05 & 97 & .14 \\
\hline Molinate & 83 & .02 & 87 & .14 \\
\hline Norflurazon & 90 & .04 & 94 & .19 \\
\hline Pendimethalin & 90 & .02 & 98 & .08 \\
\hline Propanil & 116 & .04 & 111 & .10 \\
\hline 3-(trifluromethyl)aniline (TFMA) & 68 & .02 & 80 & .15 \\
\hline 3-(trifluromethyl)phenylurea (TFMPU) & 95 & .12 & 92 & .37 \\
\hline Trifluralin & 86 & .01 & 78 & .10 \\
\hline
\end{tabular}


Table 5. Mean recoveries and relative standard deviations of selected herbicides and degradation products in groundwater samples using gas chromatography/mass spectrometry

[ug/L, micrograms per liter; RSD, relative standard deviation; --, not applicable]

\begin{tabular}{|c|c|c|c|c|}
\hline \multirow[b]{3}{*}{$\begin{array}{l}\text { Herbicide or } \\
\text { degradation product }\end{array}$} & \multicolumn{4}{|c|}{ Ground water } \\
\hline & \multicolumn{2}{|c|}{$\begin{array}{c}\text { Seven replicate samples spiked at } \\
0.2 \mu \mathrm{g} / \mathrm{L}\end{array}$} & \multicolumn{2}{|c|}{$\begin{array}{l}\text { Seven replicate samples spiked at } \\
\qquad 1.0 \mu \mathrm{g} / \mathrm{L}\end{array}$} \\
\hline & $\begin{array}{l}\text { Mean recovery } \\
\text { (percent) }\end{array}$ & RSD & $\begin{array}{l}\text { Mean reovery } \\
\text { (percent) }\end{array}$ & RSD \\
\hline Deisopropylprometryn & 99 & 0.15 & 97 & 0.20 \\
\hline Demethylfluometuron (DMFM) & 139 & .15 & 147 & .32 \\
\hline Demethylnorflurazon & 63 & .07 & 89 & 19 \\
\hline Dimethenamid & 88 & .12 & 108 & .12 \\
\hline Flufenacet & 91 & .11 & 112 & .13 \\
\hline Fluometuron & 100 & .11 & 100 & .17 \\
\hline Molinate & 71 & .09 & 88 & .15 \\
\hline Norflurazon & 63 & .07 & 87 & .18 \\
\hline Pendimethalin & 90 & .12 & 106 & .18 \\
\hline Propanil & 32 & .07 & 123 & .11 \\
\hline 3-(trifluromethyl)aniline (TFMA) & 65 & .05 & 79 & .18 \\
\hline 3-(trifluromethyl)phenylurea (TFMPU) & -- & -- & 114 & .39 \\
\hline Trifluralin & 90 & .11 & 100 & .19 \\
\hline
\end{tabular}

Table 6. Mean observed concentrations, standard deviations, and method detection limits of selected herbicides and degradation products in reagent-water samples spiked at 0.05 microgram per liter

[ $\mu \mathrm{g} / \mathrm{L}$, micrograms per liter; MDL, method detection limit]

\begin{tabular}{lccr}
\hline \multicolumn{1}{c}{$\begin{array}{c}\text { Herbicide or } \\
\text { degradation product }\end{array}$} & $\begin{array}{c}\text { Mean observed } \\
\text { concentration } \\
(\mu \mathrm{g} / \mathrm{L})\end{array}$ & $\begin{array}{c}\text { Standard } \\
\text { deviation } \\
(\mu \mathrm{g} / \mathrm{L})\end{array}$ & $\begin{array}{c}\text { MDL } \\
(\mu \mathrm{g} / \mathrm{L})\end{array}$ \\
\hline Deisopropylprometryn & 0.05 & 0.01 & 0.02 \\
Demethylfluometuron (DMFM) & .05 & .02 & .05 \\
Demethylnorflurazon & .03 & .01 & .04 \\
Dimethenamid & .04 & .01 & .03 \\
Flufenacet & .05 & .01 & .04 \\
Fluometuron & & & .03 \\
Molinate & .04 & .01 & .03 \\
Norflurazon & .03 & .01 & .03 \\
Pendimethalin & .03 & .01 & .03 \\
Propanil & .04 & .01 & .04 \\
& .05 & .01 & \\
3-(trifluromethyl)aniline (TFMA) & & & .03 \\
3-(trifluromethyl)phenylurea (TFMPU) ${ }^{1}$ & .05 & .01 & .32 \\
Trifluralin & .16 & .11 & .02 \\
\hline
\end{tabular}

${ }^{1}$ TFMPU was analyzed using a fortified concentration of 0.2 microgram per liter. 
Table 7. Absolute recoveries for selected herbicides and degradation products spiked at concentrations of 1.0 microgram per liter

$[\%$, percent $]$

\begin{tabular}{lc}
\hline \multicolumn{1}{c}{$\begin{array}{c}\text { Herbicide or } \\
\text { degradation product }\end{array}$} & $\begin{array}{c}\text { Absolute } \\
\text { recovery } \\
(\%)\end{array}$ \\
\hline Deisopropylprometryn & 109 \\
Demethylfluometuron (DMFM) & 119 \\
Demethylnorflurazon & 127 \\
Dimethenamid & 107 \\
Flufenacet & 121 \\
& \\
Fluometuron & 116 \\
Molinate & 109 \\
Norflurazon & 123 \\
Pendimethalin & 78 \\
Propanil & 92 \\
3-(trifluromethyl)aniline (TFMA) & \\
3-(trifluromethyl)phenylurea (TFMPU) & 111 \\
Trifluralin & 102 \\
Mean absolute recovery & 74 \\
\hline
\end{tabular}

\section{REFERENCES CITED}

Coupe, R.H., Thurman, E.M., and Zimmerman, L.R., 1998, Relation of usage to the occurrence of cotton and rice herbicides in three streams of the Mississippi Delta: Environmental Science \& Technology, v. 32, p. $3673-3680$.

Gianessi, L.P., and Puffer, C.M., 1995, Herbicides use in the United States - national summary report, revised April 1991: Washington, D.C., Resources for the Future, $128 \mathrm{p}$.

Hallberg, G.R., 1989, Pesticide pollution in groundwater in the humid United States: Agriculture, Ecosystems, and Environment, v. 26, p. 299-367.

Kolpin, D.W., Burkart, M.R., and Thurman, E.M., 1993, Hydrogeologic, water-quality, and land-use data for the reconnaissance of herbicides and nitrate in nearsurface aquifers of the midcontinental United States, 1991: U.S. Geological Survey Open-File Report 93-114, 61 p.
Leonard, R.A., 1988, Herbicides in surface waters, in Grover, R., ed., Environmental chemistry of herbicides, volume I: Boca Raton, Florida, CRC Press, p. $45-87$.

Meyer, M.T., Mills, M.S., and Thurman, E.M., 1993, Automated solid-phase extraction of herbicides from water for gas chromatographic-mass spectrometric analysis: Journal of Chromatography, v. 629, p. 55-59.

Thurman, E.M., Bastian, K.C., and Mollhagan, Tony, 2000, Occurrence of cotton herbicides and insecticides in playa lakes of the High Plains of West Texas: The Science of the Total Environment, v. 248, p. 189-200.

Thurman, E.M., Goolsby, D.A., Meyer, M.T., and Kolpin, D.W., 1991, Herbicides in surface waters of the Midwestern United States-the effect of spring flush: Environmental Science \& Technology, v. 25, p. 1794-1796.

Thurman, E.M., Goolsby, D.A., Meyer, M.T., Mills, M.S., Pomes, M.L., and Kolpin, D.W., 1992, A reconnaissance study of herbicides and their metabolites in surface water of the Midwestern United States using immunoassay and gas chromatography/mass spectrometry: Environmental Science \& Technology, v. 26, p. 2440-2447.

Thurman, E.M., and Mills, M.S., 1998, Solid-phase extraction: New York, John Wiley \& Sons, Inc., 344 p.

U.S. Environmental Protection Agency, 1992, Guidelines establishing test procedures for the analysis of pollutants (appendix B, part 136, Definition and procedures for the determination of the method detection limit): U.S. Code of Federal Regulations, Title 40, revised as of July 1, 1992, p. 565-567.

Ward, R.D., and Harr, C.A., 1990, Methods for collection and procession of surface-water and bed-material samples for physical and chemical analyses: U.S. Geological Survey Open-File Report 90-140, 71 p.

Wauchope, R.D., 1978, The pesticide content of surface water draining from agricultural fields - a review: Journal of Environmental Quality, v. 7, p. 459-472.

Zimmerman, L.R., and Thurman, E.M., 1999, Method of analysis by the U.S. Geological Survey Organic Geochemistry Research Group - determination of triazine and chloroacetanilide herbicides in water by solid-phase extraction and capillary-column gas chromatography/mass spectrometry with selected-ion monitoring: U.S. Geological Survey Open-File Report 98-634, 21 p. 